\title{
Perspectives of Albanian Criminal Procedural Legislation in the Context of European Union Integration
}

\author{
PhD Candidate Klodjan Skënderaj
}

\section{Doi:10.5901/ajis.2014.v3n1p179}

\section{Abstract}

The judicial cooperation in the criminal field is based on the solidarity principle between different countries, where each state should assist and at the same time be assisted in fulfilling the primary obligation of criminal offences prevention, offering justice and execution of criminal sentences. To fulfill the mission of a common justice, each of the countries should contribute to realize it even if it would harm any specific interests of a certain country. Thanks to such collaboration it is possible to realize criminal justice, so that the authors of criminal offenses regardless the place where they are sheltered or where they have committed their criminal activity, come before justice and at the same time receive and execute the relevant conviction. Basing on the above mentioned and trying to give a definition to the notion of judicial collaboration in the criminal field, we would consider that it represents "the legal relationship", which is established between the states, in all cases when the competent authorities of criminal proceeding are not capable to act beyond the terrestrial jurisdiction where they fulfill their functions, because of location of the author of criminal offense or of the crime scene. In these circumstances, in all forms of judicial cooperation, the subjects of legal relation are the state which asks for establishment of this collaboration (defined as requiring state) and the state to which this collaboration is required to (defined as the required state). The judicial collaboration in criminal field includes these forms or real mechanisms a) extradition, b) mutual legal assistance c) transfer of criminal proceedings, $d$ ) recognition and execution of foreign criminal sentences. The main means of judicial collaboration to which is paid a special importance in such collaboration is the institute of extradition which results to be the most applicable form by various states. In this paperwork the focus will also include the study of the newest form of judicial relation between EU member countries, like the European Arrest Warrant, which is based on the principle of mutual recognition of sentences. In the context of Albanian state accession perspective in common European space, it is worthy to recall that one of the obligations Albania has undertaken, is the general legislation harmonization and especially the criminal procedural one. In conformity with requirements of European Union, Albanian legislator has to undertake real steps to unify the legislation and one of the principal fields are the instruments of judicial cooperation in criminal field, for which the actual legislation is not sufficient.

Keywords: judicial cooperation, jurisdictional relation, extradition, European arrest Warrant, letter of application, convention, Code of criminal procedure.

\section{History of Criminal Collaboration Relations between Albanian and Other Countries}

Referring to a historic and comparative overview it is obvious that the international cooperation in criminal field has had a general progress in the modern law era.

At this point, Albania considering its specifics regarding the moment of recognition as a state in world arena, its geographic position but even the sort of politic regime that ruled in, has submitted late developments in this field of law.

Making a retrospective and chronological analysis, it is worthy underline how the jurisdictional relations of Albania with the other states have been evolved.

It should be stressed that after the independence proclamation, Albanian state formed a considerable legislative basis regarding the jurisdictional relations with the foreign states in criminal field, becoming party of some of significant treaties of the era.

The first treaty for extradition is undersigned with Greece on the $25^{\text {th }}$ of June 1925 . Other extradition treaties come later like the one with Great Britain, and with the Kingdom of Serbia, Croatia and Slovenia. At the time of monarchy regime, Albania approved a modern legislation using the best models of that time and actually the Italian and French one.

Basing on this legislation, without negating the politic will of that time to coordinate the forces together with other states in the fight against criminality, the cooperation in the criminal field had an important development which was finalized in signing several bilateral agreements.

Here, we can mention an international act of special importance for that period, the treaty concluded between Albanian Kingdom and the United States of America ( treaty concluded date 01.03.1933).

Beyond the juridical and historical importance of this treaty, it is also an index of the will of political class to 
establish the cooperation in criminal field not only with the region countries but even beyond the ocean.

Though this treaty has never been denunciated at any time by the participating parties, it is interesting the fact that nowadays there is the problem of its legal power.

In our adjudication, the legal value of this treaty and as a result its application by our judicial practice is debatable, because failure of its execution for a long time period has made its norms fall to desuetudo ${ }^{1}$.

Although, in parallel with this doctrinal debate, the approval of a new agreement in the near future between the Republic of Albania and the United States of America seems to contribute at least to the future, cancelling this legal debate (Ministry of Justice, 2008).

After the Second World War the ancient continent was separated in two camps and the block of European states that went on the side of Soviet Union, created their international norms. Basing on the regime of that time, Albania represented an autarkic state, and in these conditions, the economic isolation was normally accompanied by a juridical isolation.

Our legal system was based in the territoriality principle of criminal law execution, which in conditions of an isolated Albania, was enough taken into consideration for the prevention and fighting of criminality. Pursuant to this fundamental principle, the code of criminal procedure of that time did not provide a general arrangement about forms of cooperation with the foreign authorities (Hoxha, Extradition according to the EU legal instruments. Similarities and differences with instruments of Council of Europe, 2010).

Found in these political and legal circumstances, during this period, Albania has concluded only some bilateral conventions and these were only with the states of ex communist camp. (For the extradition and mutual assistance in criminal matters, 1959) (For juridical assistance in civil, family and criminal cases, 1960)

Whereas the real and inherent development of cooperating relations with the foreign states started after the big changes of the political regime after years ' 90 .

At this time, Albania became a member of several international organizations and as a consequence undersigned and ratified the main international agreements that establish the judicial collaboration in criminal field in general and on extradition especially.

On the other hand, the approval of a modern legislation and actually of the Criminal Code and of the Criminal Procedure Code, respectively in years 1994 and 1995, can be considered as normative acts which reflected the extradition in harmony with European standards set by the conventions of European Council ( For reciprocal juridical assistance in criminal matters, 1999),( For extradition, 1998), their additional protocols, and the recommendations approved in their execution.

\section{Terms and Procedure of Extradition}

In order to give a definition to the concept of extradition the way this institute is arranged by the modern law, we would consider it as "a form of international judicial collaboration in criminal field, which represents the procedure through which one state (the state to whom it is requested) agrees to consign to another state (the requesting state) an individual who is found in its territory, who is criminally prosecuted or is sent to the court for committing a criminal offense, or is requested to execute a criminal sentence, in the requesting state".

Considering the particularity of extradition as an act of sovereignty of requested state, the central authority which as a rule is the Ministry of Justice, plays a significant role to fulfill this procedure.

So, in most part of states, the extradition is decided by an executive authority (As executive authority in USA is the State Department, in France and in Spain is the Council of Ministers, in Canada and in Italy is the Minister of Justice), which as a rule is also based on a judicial sentence, which in general plays a consultative role.

In Albanian law system, extradition is provided by the Constitution, the Criminal Code, the Code of Criminal Procedure and the international Agreements where the Albanian state is a party of.

Basing on article 39 of the Constitution "Extradition can be allowed only when it is expressively provided by the international agreements where Republic of Albania is a member and only with a judicial sentence".

At the same time, extradition is established by the provisions of criminal procedure, respectively by the articles 488

\footnotetext{
${ }_{1}^{1}$ Falling to desuetudo according to political opinion, represents the situation when the juridical norm, without being abrogated expressively or in silence, does not find the terrain to be applied, has not terrain to be applied, has no object, and as a result becomes surpassed, as a consequence of evolution of social relations.
} 
and 504, which are compiled in full conformity with the provision of European Convention "For Extradition".

According to these provisions, the extradition is applied if none of prohibition cases is applied, which are:

a) the requesting state has to guarantee the condition that the extradited person will not be proceeded, will not be convicted, will not be held on purpose of execution of a sentence or of a security measure and will not have any other individual restriction for another criminal offence except the one for which the extradition is given.

Known also as the "Specialty principle" this condition is also provided by the European Convention for Extradition and the Code of Criminal Procedure. This principle is specified by law no. 10193 date 03.12 .2009 through which it is made an intervention by the legislator regarding the specification and un information of extradition procedures.

It is the case to underline that these criminal offenses for which the absence of proceeding must be guaranteed, are the ones committed by the person before he is consigned because of extradition.

b) Extradition is not allowed when the criminal offense for which the person is required, is not such provided at the same time by the requested state's legislation. This term is also known as the principle of 'double criminalization" and it is provided by the Albanian legislation and by article 2 of the Convention "For Extradition" at the same time.

c) Extradition is not permitted in case when the requested person is an Albanian citizen and when there is no deal to provide diversely. In execution of European Convention for Extradition "citizenship objection" is considered as a refusal reason, basing on fact that this provides the individual a social defense, at least in the context when a foreign sate makes an extradition request for a citizen of the country to which the extradition is required.

Like it was emphasized at the beginning of this paperwork Albania has accepted the extradition of its citizens only with USA to that state and vice versa, basing on the treaty of "For Extradition" of 15t of March year 1933. In practice there is a debate if it is still in force, by sentence no. 241 date 22.05.2001, The district Court of Tirana accepted the power of this treaty and decided the extradition of Albanian citizen to the New York state, on condition that he is not prosecuted or consigned to another state for various charges for which he is extradited..

d) Extradition is not given for criminal offenses considered as political acts or when the persons results to be wanted for political reasons. In application of this provision, the state to which extradition is asked, that means Albanian state, is allowed to decide when a criminal offense is considered a political one. The Convention of Council of Europe "For Extradition" provides expressively which criminal offenses are not considered political ones. So in execution of this convention, the attempt to murder the president of state or one of his family members is not considered a political one. A very troubling and evolved is the phenomena of terrorism acts which in most cases are because of religion or political reasons. We underline that basing on Convention of Strasbourg "For the suppression of terrorism" of date 27 January 1977 in article 2 it is cited that "these acts for extradition purpose will not be considered political criminal offenses

e) Extradition is not permitted when the requested person is concluded that will be prosecuted or will be object of discrimination because of his race, religion, sex, citizenship, language, or political convictions, his personal or social status, or of or of other sentences or wild treatments, inhuman or offending acts which are violations of fundamental rights.

f) Extradition is also not allowed even in the case when the criminal offense for which he is requested, the person has been proceeded or judged in the country to which the extradition is requested, even though the criminal offense has been committed beyond its borders.

g) Extradition is not allowed even when the person for whom the extradition is requested has committed a criminal offense in Albanian territory².

h) Extradition is not allowed when for this criminal offense Albanian state has given the amnesty.

i) The request to allow the extradition will be also refused when the law of requesting state provides criminal prosecution or sentence for the offense committed.

Though the above mentioned terms provided in the code of criminal procedure are not the only ones, because we recall that Albanian legislator has made a legislative intervention with the Law no. 10193 date 03.12.2009, sanctioning

${ }^{2}$ The meaning of territory of Albania is given in article 5 of criminal code. It is important to underline the fact that not only for the whole criminal offenses but even if a part of them is committed in Albania, the extradition cannot be given. 
some other terms too. This intervention of legislator has happened as a further juridical arrangement of judicial cooperation, which has brought further specifications of the existing provision.

It is noted that these terms have been implemented as a result of need in many cases of judicial practice, and also as a consequence of uniformity of Albanian criminal procedural legislation with the ones of the other countries.

These terms are applied in extradition cases of a person, to a foreign state and actually they are: a) the Albanian legislation must provide for the criminal offense, for which the foreign state has assigned a restrictive security measure, a conviction with imprisonment not less than a year, $b$ ) the measure of conviction or the residual part of conviction given by judicial sentence of final form is at least 4 months at the time of the request submission for extradition, c) the criminal prosecution or the execution of the criminal sentence should not be prescribed according to the legislation of requesting state, ç) should exist the conditions to restart the criminal process in the requesting state, though the criminal proceeding in Albanian, for the same criminal offense is ceased, d) the requesting state has to give a guarantee that he will not apply a conviction to death or if such is given, will not be executed, $\mathrm{dh}$ ) the person for whom the extradition is requested, at the time of presenting the request for extradition, has not applied or has not been given an asylum in Albania to the requesting state.

In case none of the options mentioned above of extradition prohibition exists, the Ministry of Justice sends the acts to the prosecutor of the competent court. The competent Court that examines the request for extradition notifies the parties at least ten days in advance the date set for the judicial session. When the court decides pro the extradition, the court decision can be appealed by the side of the parties to the court of appeal, according to the general rules of appeal. In this case, there comes the conclusion and the decision of this court to dispose the extradition finally. When the court decides to refuse the request of extradition because of one or more causes, then the Ministry of Justice does not permit the extradition.

Considering that finally the Ministry of Justice has the competence to dispose the request of a foreign state for extradition, according to article 499/1 the Ministry has to do this in thirty days since the day the court decision became final. In case the Ministry does not decide within this term, then the person for whom the extradition was required, and who is found imprisoned in jail, is freed. When the extradition is permitted, the Ministry of Justice must also define a date to consign the person to the authorities of requesting state.

\section{Replacement of Extradition with European Arrest Order}

In general context of integration process in which Albania is actually, the harmonization of domestic legislation governing judicial cooperation in criminal matters with acquis communautaire, is presented as a priority in the field of legal and institutional reform. On the other side, in conditions when the trans boundary criminality has been extended a lot, the judicial cooperation in criminal matters should be, together with informative services cooperation between the national organs of order, one of the most efficacious instruments in disposal of European states to balance this phenomena, so the reforms that Albania should commit must access all the European acts that simplify such cooperation.

In order to fulfill this goal, the Albanian legislation must aim the approval of a special law for the judicial cooperation in criminal matters between the EU member states, which would give access to cooperate with them, to apply the special provisions that simplify sensitively the judicial and police cooperation in criminal matters.

In this legislation it must be included the European Arrest Order, which main objective is to replace the extradition procedures with the simplified procedure of arrest and consignment of the requested person who is in the common space. It is the occasion to recall that the Framework decision 2002/584/JAI of EU Council, of $13^{\text {th }}$ of June 2002 which aims to issue and execute the European Arrest Order, is not directly executed, so after the accession of Albania to EU, it is true that "an automatic consigning" of wanted person is not going to happen, but according to the case, firstly Albania is required to implement this Framework Decision in its domestic legislation.

Of course, this replacement between the conventions of European Council and the juridical EU norms will exclusively operate in relations of criminal cooperation between the member states, whilst between Albania and the other countries not members of EU will proceed with the classical extradition procedure as it is provided by the conventions of Council of Europe. The replacement of extradition procedure provided by the code of criminal procedure and the conventions of European Council where Albania is a party, will be a pro parte and not in integrum replacement.

Saying this, it is clear that Albania is in a continuous process which presents a series of challenges where the most important in our interest field is the confrontation of Albanian legislation with the Framework decision of European Arrest Order. This process will be accompanied undisputedly by changes of material and procedural provisions of our criminal legislation and in some cases even of constitutional provisions. 
In any case, the implementation of European Arrest Order will change the sense and as a result the interpretation of some of fundamental principles of criminal law and criminal procedure law. Encountering the increase of criminality phenomena has to be balanced with the delicate matter of defending the fundamental values provided by our inner legislation. In this complex frame, which partly includes even the sphere of personal freedoms of the citizens, there comes the question if the Albanian legislator has to give the priority to the execution of European norm, which imposes the efficiency of international cooperation, or of constitutional principles.

Regardless the undisputable efficiency that accompanies this new mechanism, necessary to face with an unlimited criminality, it should be underlined that it has to be treated with the necessary exigency to avoid the threatening of guaranteed freedoms, on which modern civilizations are generally based and especially the democratic countries.

Therefore, it is important that the controversial elements that accompany this juridical instrument, become the object of debate and analysis, and see the chance to gain from the guidelines of the Constitutional Courts of judicial practice of member States, which have already implemented the European Arrest Order to their legislations.

In this viewpoint, we will deal shortly with some of issues that will accompany the adoption of this form of judicial criminal cooperation in Albanian law system.

\section{Execution of European Arrest Order, between Respecting of European Norms and Fundamental Principles of Albanian Law System}

From all the polemics that have accompanied the implementation of European Arrest Order in domestic law, the attention of law executors is attracted by the anti constitutional risks that come with application of the framework decision. The European Arrest Order, conceived as a new alternative against the extra extended procedures of classic extradition, which are incompatible with the requirements of simplification and efficiency that should accompany the common socialeconomic space, brings anti anti constitutionality risks, properly in those directions where the Arrest Order is avoided from the classic extradition procedure.

As a rule, a new resource of law is the law that will include the European Arrest Order in our legal order, can avoid several of law principles; but, several limitations that this normative act provides regarding the fundamental principles can not be avoided. So, the practice of Italian Constitutional Court has many times emphasized the reasoning of sentences given by it, the impossibility to threaten the fundamental rights provided by the constitution, even in the hypothesis when this avoidance is realized by European norms.

In this line of ideas we should underline that the experience of the other countries has shown that the tale quale execution of the framework decision, in several times has not been possible. ${ }^{3}$ Using this experience, the Albanian legislator must realize the necessary constitutional changes that will make possible the compatibility of the fundamental act of European Arrest Order, or to provide the legal regime of Arrest Order, in the spirit of constitutional principles.

Though not a direct resource of judicial cooperation in criminal matters, the Constitution of Republic of Albania, in quality of fundamental law provides the fundamental principles to which will be subject the restriction of personal freedom in general and the extradition especially. Moreover, we are analyzing the problematic situation of implementation the European Arrest Order to our domestic law, in viewpoint of these constitutional principles.

\section{The European Arrest Order and the Extradition of Albanian Citizens}

The article 11 of Criminal Code provides the same formulation as article 39 second paragraph of the Constitution, adding in the third paragraph that "extradition will not be allowed if the person to be extradited is an Albanian citizen, except the cases when the agreement provides diversely".

After a long period in which the European states have established the basis of a judicial criminal cooperation and have made continuous attempts to develop further these forms of cooperation, it has come the moment considered inevitable by many researchers: the sovereignty limitation and as a result giving up from the principle of citizenship (Racsmany \& Blekstoon, 2005).

After the approval of Framework decision, the member states cannot refuse the consignment of the charged

${ }^{3}$ It is sufficient to recall here the changes made to some of constitutions of member states before the approval of interior implementation law in France, Italy, Slovenia, Rumania, and others, or the anti constitutional announcement of the law which implemented the Arrest Order in some of member states like Germany, Poland, Cyprus and others. 
person or of the convicted one with the motive that the person has the citizenship of the country of execution of European Arrest Order. For this, basing on elimination of the reason to refuse because of citizenship of requested person, some of the member states have reviewed the legal provisions, even the fundamental law.

In European context, even Albanian legislator has to accept that the framework decision that regulates the European Arrest Order has abrogated the principle of citizenship. In application of this decision, the existence of Albanian citizenship of the requested person, this will not be considered an obligatory reason to refuse the execution of European Arrest Order.

However, Albanian law can implement the objection of albanian citizenship of the requested person as one of facultative reasons to refuse the execution of Arrest Order, in execution of article 5, third paragraph of the framework decision, which provides this possibility conditioned by several premises. So, when this order is issued on purpose of criminal prosecution, the court can condition the consignment by the fact that the requested person must return to Albania to execute the conviction which eventually will be given against him.

Otherwise, when European Arrest Order is issued to execute the conviction of an Albanian citizen, the legislator should take into account "the objection of nationality" and in cases when the conviction is in conformity with the Albanian legislation and the Albanian competent authorities undertake to execute this sentence, the court can refuse to consign the Albanian citizen. In any case, the execution of conviction in the country of origin will be realized by consent of member state that has issued the Arrest Order.

\section{The Compatibility of the Principle of "Double Criminalization" and the Legitimacy of the Criminal Offences with the Provisions of Framework Decision}

In application of provisions of framework decision, in the law which will regulate the European Arrest Order, will not find the application - at least in the meaning we have given to this norm up to -, the article 11 , second paragraph of criminal code, according to which, "extradition is permitted when the criminal offense where the object of request for extradition consists of, is at the same time such provided by the Albanian law and the foreign one.

Although, the cohercetive execution of the Arrest Order, without a preliminary verification of double culpability, can be considered in objection with the above mentioned article, which in the context of a general principle, is not referred only to the classic procedure of extradition provided by the code of criminal procedure, but of any form of cooperation that is based on arrest of a person and on his consignment to another state.

This choice provided by the framework decisions is considered by many authors to be in objection with legitimacy principles provided by the Constitution, as the act is called a criminal offense in the country that issued the Arrest Order, even though it can be part of generic hypothesis provided by the framework decision, it could not meet all the necessary elements to be considered a criminal offense by interior domestic law to execute the European Arrest Order.

Therefore, even the article 29 first paragraph of the Constitution of Albania provides the principle of nullum crimen sine lege, according to which "no one can be convicted for a criminal offense, which is not such considered by law at the time of being committed..." The same principle is provided by article 2 of criminal code in this way "No one can be criminally convicted for a criminal offense that was not previously provided expressively as a crime or as an offense by law".

Another principle seems to be threatened, the one of determining the legal facts, considering that the framework Decisions makes such a wide regulation of some of 32 criminal acts, that it leaves space for an extended interpretation of them, an unknown reality for our system of criminal law interpretation.

Practically, the consignment will be realized for a conduct formally part of the typology provided by article 2, paragraph 2 of the framework decision, but which does not meet all the constitutive elements that characterize the crime to be "equivalent" in our domestic law system, in other words, it is not considered a criminal offense by the albanian legislation4.

To avoid this constitutional incompatibility, the legitimacy principle should be read with more flexibility. That means, following this idea, the legitimacy principle acts in the sense that it is obligatory for the fact to be legally provided as a criminal offense, though only by the law of state that requires the consignment of the person. (Cassese, 2003, p. 1565)

\footnotetext{
${ }^{4}$ In fact, if we actually refer to the list provided by article 2 of the framework decision, we are convinced when we ascertain the nature of several of these criminal offenses like: ex "corruption"; "deceive"; "cyber crime"; "environment crime"; "racism and xenophobia", and we also refer to the criminal specifications made to the corresponding criminal act/acts in our inner legislation.
} 
Reasoning this way, the interpretation can also be reached referring to another starting point, the one that the legitimacy principle applies only for the criminal offenses committed in the national territory and the judgment is going to be held there too.

Thus, in case of European Arrest Order, the member executing State, will not judge the arrested person for the criminal offense committed by him, but will only consign him. In other words the executing state will only help for the investigation or the execution of another country court's sentence, so the principle of legitimacy does not need to be respected by this state either.

The authors who support this opinion add also the argument according to which, if we apply the principle of legitimacy strictly even in such case, the authors of criminal offenses can avoid the investigation or the execution of conviction having shelter inside a the territory of a state where the committed criminal offense is not provided by law, creating this way "the criminal paradise".

In fact, it is inherent the refuse to accept this thesis in front of the principle of taxative determination of criminal offenses, which implies that the fundamental law does not allow for anyone to undergo the conviction for facts that legislator has not provided to threaten the social values and as a result deserve to be criminally punished.

Attaching to the opinion of some other authors, in our judgment, the exclusion of the list of 32 criminal offenses represents and is based not on the avoidance of the legitimacy principle, but on presumption that this principle is applied for the list of 32 criminal offenses, since the moment of their selection by the designers of framework decision (Selvaggi \& Villoni, 2002).

In other words, the list provided in article 2, paragraph 2 of the Framework decision, represents the individualization of the common social values zone of EU countries and gives to all the possibility to sanction them criminally according to the special forecast in their inner legislations.

On such presumption, the preliminary verification of the condition of double culpability is "disregarded", which in these cases will be considered to be valid.

In the last analysis, few alternatives have remained to the Albanian legislator, for as long as the politic solution in the EU context has been as exactly as restrictive: to approach the criminal legislation in conformity with European standard.

\section{Cases of Personal Freedom Restriction; Detention Measure and Right of Appeal}

A special analysis must be paid to the compatibility between the new instrument of European Arrest Order and cases of personal freedom restriction, which as a rule are provided by the fundamental law. In this line of ideas we recall that even the Constitution of Republic of Albania sanctions a series of principles related to the cases of imprisonment and the maximal terms in which the person freedom can be restricted; the legal process, principles applied not only for Albanian citizen but even for the foreigners who submit the procedures of detention and consignment.

According to a group of authors, in case of EAO execution, technically the detention restrictive measure is taken by an authority that does not have the exclusivity by the inner legal order to imprison the person's freedom (Gualtieri, 2003).

In these circumstances, it is proposed that the domestic law which regulates the Arrest Order should allow the recognition of motives for which the arrest measure is taken by the judicial authority issuing the European Arrest Order and must forecast that this order must be issued from a judge. As a result, the person who is subject of such order has to be listened, to enjoy the quality of being charged of, and be notified about the reasons of the arrest measure request.

In our judgment, these opinions are based on a wrong premises because they equate the freedom restriction as a consequence of detention realized by the executing state and the arrest performed as a result of taking the arrest security measure, in conditions of criminal procedure code. The European Arrest Order is an instrument that applies the mutual recognition of judicial sentences in criminal law field.

Ratio legis of the framework decision accepts that the judicial authority of the state in which territory is found the arrested person, cannot assess the measure already taken by the court of another member state, but it will control only the formal terms related to the consignment of requested person. In other words, the Albanian court to execute an European Arrest Order will not be expressed on merits/legality of the measure accommodated by the judicial authority of the requesting state.

Therefore, different from the extradition procedure, if the court ascertains the existence of an European Arrest Order, will dispose the detention of the requested person and will judge immediately the request for consignment to the requested state, without judging if the terms of Albanian legislation for taking the restrictive arrest measure are met or not. In these circumstances, the Albanian judicial authority to execute an EAO will give a tout court consent regarding only to 
the formal conditions for which the respective order has been given and not on the control of legitimacy title on which basis the personal freedom is restricted.

So, the Albanian law on execution of framework decision should provide the verification of several formal elements of the content of European Arrest Order, respectively: the existence of a final judicial sentence; the arrest security measure taken, or any other sort of applicable judicial sentence with the same consequences.

The Albanian court can not extend the examination even to the terms of giving the restricting measure which is examined by the authority of the European Arrest Order issuing state. Of course, the objection as un based on law and proofs of the sentence given by the member state which has issued the Arrest Order, will be realized in the state that issued this sentence, where the person to be consigned will profit from all the procedural rights and warrants.

The Albanian law that will provide the Arrest Order should regulate all this procedure in details, so that it can be realized in conformity with constitutional principles. So, at the detention moment, the requested person must be informed about the reasons of being arrested and about the existence of a European Arrest Order; to give him the chance to inform his family or other familiars; to be informed with the content of Arrest Order; to let him know the possibility he has to give the consent or not about his consignment to another member state; and about other procedure rights, as the right to have the free assistance of an interpreter; to be guaranteed defense through assistance of a lawyer; to be granted a free defense; to communicate freely and in private with his lawyer and so on.

Basing on all we mentioned, it depends on assessment of Albanian lawmaker which through the law that regulates the EAO can condition the execution and consignment of the requested person by providing the cases for which the Arrest Order is issued. In our judgment, such forecast is not necessary to assess the compliance with fundamental values granted by the inner legislations.

A special problem can be raised regarding the right of appeal against the arrest measure, in order to respect the principles provided by our inner legislation and above all the article 28, third paragraph of the Constitution, a norm which regulates the right of appeal against the judge decision as one of procedural guarantees, granted to the person subject of restricted freedom measure.

But a constitutional right like this - which has to be provided even by the law that will establish the Arrest Order -, should respect the time limit provided for the execution of consignment of the person according to the European Arrest Order, limits which are expressively provided in the framework decision. In application of article 17, these terms will be: 60 days and in special cases they can be extended to 90 days; while in case when the consent of the person himself has been already taken, this term is only 10 days.

In these circumstances, in order to make possible and feasible that all the European Arrest Order mechanism and the procedures of consignment be realized within these terms and at the same time all the procedure rights and warrants be respected as provided by the domestic law in favor of the person deprived of liberty, it needs to provide "a preferential way" for all complaints that are based on execution of European Arrest Order.

Basing on what we argued above, it is the case to recall that the sentence accepting the Arrest Order can be appealed only for how the terms are respected in conformity with the framework decision in which the Arrest Order must be executed, and not for "legitimacy" of the title on which basis the European Arrest Order has been issued.

Such delicate verification to what the fate of citizen in extradition is depended to, will be trusted to the inner procedures of the requesting state. But, it should be accepted that the EU member states have similar legal provisions, regarding the content; modalities and time of verification, so it can not be a priori accepted that the constitutional warrants can be met through a mutual trust to various EU states' legislations, though the level of democracy in some cases does not even guarantee the defense of fundamental human rights and freedoms. In these circumstances, the Albanian law can provide even other additional guarantees as a condition to execute the European Arrest Order.

\section{Perspective of Albanian Procedural Criminal Legislation}

Nine years after the creation of European Arrest Order, it is concluded that in the context of criminal cooperation of EU member states, the extradition procedure has remained in second plane. The success and efficiency are two terms which synthesize in general the actual balance of European Arrest Order. These are the conclusions of assessment reports of the Commission for implementation of European legislation in the field of criminal collaboration between the member states.

From a report of judicial criminal cooperation held basing on this juridical instrument, it is evident that this 
mechanism has brought to main changes: the considerable simplification and acceleration of procedures and the intensification of their use in practice ${ }^{5}$. In this sense, it is doubtless that EAO represents a proved progress, comparing to the extradition procedure.

However, some legislative obstacles that limit the execution in practice need to be surpassed in order to use the potential offered by the European Arrest Order.

Thus, the optimism for this new mechanism is somewhat faded from the existence of some problems encountered during the implementation of this order to the inner legislations of some member states. In this context, it must be stressed that the approach of domestic law with the European one or the implementation of acquis communitaire to the domestic law seems to be a very complex process. So, the elimination of some of the reasons to refuse extradition; the consignment procedure itself; determination of competent judicial authorities; respecting the requested person's rights, are only some of the most discussed issues that have accompanied this new procedure.

In these circumstances, you see that the procedure of designing and approving a law to implement EAO to our legal order, must be accompanied by a specialized analysis in order to certify if and at what extent, the inclusion law will be compatible with the principles of our legal system, avoiding this way the further possible constitutional controversies and conflicts, as it has happened in some of member states. In our judgment, the practice of the other member states takes a special importance in this respect.

Basing exactly on the experience of states which have already passed a process of political and juridical debates, but also of judicial disputes regarding the validity of the law which has applied this mechanism to their domestic legislation, it is slightly understandable that the job of law designers to implement EAO to our inner legislation will not be an easy one.

In execution of the principles of acquis communitaire, the member states have the obligation to reach the result provided by the Framework decision No. 2002/584/JAl through their domestic legislation. Consequently, Albania has to choose the legal instrument or the form through which it is going to be processed.

These legal norms can be implemented to the code of criminal procedure as it has already happened in French law system, Law no. 204, date 9.03.2004. After coming to force of this law -12 March 2004-, articles 695-11 to 695-51 criminal procedure code, constitute the legal framework that establishes the European Arrest Order and the procedures in French legal system, or to a special law, as it has happened to Italian system.

Regardless the specific legislative technique in use, these changes will represent a set of juridical norms through which grosso modo will be regulated, the field of executing of European Arrest Order, the reason of refusing EAO, the competent court to examine this order in cases of execution procedure or of the procedure of issuing this order, the procedure of executing the order and the terms to execute within, the procedure of transferring the requested person to the state which has issued the European Arrest Order, the competent authorities and everything else.

Considering that the European Arrest Order represents a special mechanism of criminal judicial cooperation, which is based on mutual recognition of judicial sentences, results that its legal regulation will be different from the one of the other forms of cooperation. In this context it is the case to underline that the provisions of criminal procedure code which govern extradition, though they come in objection with some of principles of Arrest Order, will continue to be in force. These provisions will be applied in all extraditions requested or to request to the other states, non member of European Union.

Regarding the legislative technique in general and especially the design of law content for the execution of European Arrest Order, Albanian legislator first will refer to the provisions of framework decision, which includes the main procedural elements on which this legal instrument is based. On the other hand, a special importance will be paid to the provision of criminal procedure code, which represents the legal framework where the principles of a criminal process are provided and therefore the elements to be evident are the ones which continuously will be subject of this law regulation or will profit by a special regulation.

${ }^{5}$ Only in first 5 years, the execution of this procedure has made the localization and detention of 1770 wanted persons, among them 1532 were consigned by the national authorities something that represents an improvement to the mass of $25 \%$ in ratio with the situation of a year before. France, Poland, Spain, Great Britain and the Low Countries, are counted as states that issue and take the biggest number of European Arrest Orders. Also, the duration of procedure has fallen sensitively. 


\section{References}

Cassese, A. (2003). Diritto penale e processo. Revista Giuridica, 1565.

Gualtieri, P. (2003). Convegno sul mandato d'arresto europeo. Urbino.

Hoxha, A. (2010). Extradition according to the EU legal instruments. Similarities and differences with instruments of Council of Europe. Tiranë: Morava.

Hoxha, A. (2010). L'integrazione dell'Albania nell'UE. Estradizione e cooperazione giudizaria in materia penale. Bari; Cacucci.

Islami, H., Hoxha, A., \& Panda, I. (2010). Komentar i Procedurës Penale. Tiranë: Morava.

Miçi, A. (2004). Marrdhëniet juridiksionale me autoritetet e huaja. Jeta Juridike , 32-39.

Ministry of Justice. (2008). Work Plan. Retrieved from mail.justice.gov.al

Parlamenti i Republikës së Shqipërisë. (Ligji nr. 7905 datë 21.03.1995). Kodi i Procedurës Penale. Tiranë: Alb Juris.

Parlamenti i Republikës së Shqipërisë. (Ligji nr.7895 datë 27.01.1995). Kodi Penal. Titanë: Qëndra e Publikimeve Zyrtare.

Qeleshi, J., Kalaja, F., \& Bozo, R. (2010). Ekstradimi midis kuadrit normativ të Këshillit të Europës dhe Bashkimit Europian. Jeta Juridike, 17-32.

Racsmany, D. Z., \& Blekstoon, R. (2005). Falling of rejection of nationality in the European extradion. Jurnal Europina of criminal offenses , 317-363.

Selvaggi, E., \& Villoni, O. (2002). Cassazione Penale. Giuffrè.

Extradition, Albania - Greece. (1925, June 25).

Extradition, Albanian Kingdom - United States of America. (1933, March 01).

For the extradition and mutual assistance in criminal matters, Albania - Czechoslovakia. (1959).

For juridical assistance in criminal matters, Albania - Rumania. (1960).

For extradition and mutual assistance in criminal matters, Albania - Hungary. (1960).

For legal assistance in civil, family and criminal cases, Albania - Russia. (1960). 